\title{
Assessment of soil physical attributes at sowing row and inter-row under no-till system ${ }^{1}$
}

\author{
Atributos físicos do solo na linha e entrelinha de semeadura no sistema plantio direto
}

\author{
Julius Blum²*, Neyde Fabíola Balarezo Giarola ${ }^{3}$, Álvaro Pires da Silva ${ }^{4}$, Osvaldo Guedes Filho ${ }^{5}$, Sâmala Glícia \\ Carneiro Silva ${ }^{4}$, Diogo Néia Eberhardt ${ }^{6}$ e Suzana Romeiro Araújo ${ }^{7}$
}

\begin{abstract}
In no-till systems, two different soil conditions are created during the sowing operation: row and inter-row positions. The objectives of this study were to evaluate, using static and dynamic soil attributes, the influence of no-till sowing operation on creating better physical environment for soybean crop growth. A field transect with clay content ranging from 150 to $400 \mathrm{~g} \mathrm{~kg}^{-1}$ was selected in Ponta Grossa, Paraná State, Brazil, from a Typic Hapludox that has been cultivated under notill system for 16 years. After soybean harvest, 68 undisturbed soil samples were collected at both sowing row and inter-row positions. The following soil properties were evaluated: saturated hydraulic conductivity, air permeability, bulk density, total porosity, soil moisture at field capacity, texture, and total organic carbon. Multiple regressions among dynamic and static soil properties were fitted, and differences between sowing row and inter-rows were tested by paired $t$ test. Saturated hydraulic conductivity and air permeability were positively correlated with macroporosity $(r=0.75$ and 0.74 , respectively; $p<0.001$ ). Total porosity, bulk density, air permeability, and macroporosity were position-dependent. In general, soil physical quality was higher at row position due to lower bulk density and higher total porosity, hydraulic conductivity, air permeability and macroporosity.
\end{abstract}

Key words: Soil physical quality. Soil conservation tillage. Soil compaction. Air permeability. Saturated hydraulic conductivity.

RESUMO - No solo, a operação de semeadura direta aparentemente cria ambientes com condições diferenciadas para o desenvolvimento das culturas: as posições linha e entrelinha. O objetivo desta pesquisa foi avaliar a influência da semeadura direta em criar ambientes (linhas) com maior qualidade física do solo para o desenvolvimento da soja, por meio de atributos físicos estáticos e dinâmicos. O estudo foi realizado no município de Ponta Grossa, estado do Paraná, Brasil, ao longo de uma transeção em Latossolo Vermelho distrófico, cultivado há 16 anos no sistema plantio direto. Após a colheita da soja foram coletadas 68 amostras de solo com estrutura indeformada nas posições linha e entrelinha de semeadura. Foram determinados os seguintes atributos: condutividade hidráulica saturada, permeabilidade ao ar, densidade do solo, porosidade total, conteúdo de água na capacidade de campo, textura do solo e carbono orgânico total. Foram testadas correlações múltiplas entre as propriedades físicas estáticas e dinâmicas do solo e comparados, pelo teste t, os atributos físicos do solo determinados na linha e entrelinha da cultura. As propriedades dinâmicas condutividade hidráulica saturada e permeabilidade ao ar correlacionaramse positivamente com a macroporosidade ( $\mathrm{r}=0,75$ e $0,74, \mathrm{p}<0,001$, respectivamente). A porosidade total, densidade do solo, permeabilidade ao ar e macroporosidade foram dependentes da posição linha e entrelinha e da ação de raízes. Ao longo da linha de semeadura, o solo apresentou qualidade física superior ao da entrelinha, o que foi comprovado pela a redução da densidade do solo e aumento da porosidade total, condutividade hidráulica, permeabilidade ao ar e macroporosidade.

Palavras-chave: Qualidade física do solo. Sistema de semeadura direta. Compactação do solo. Condutividade hidráulica. saturada. Permeabilidade ao ar.

\footnotetext{
*Autor para correspondência

${ }^{1}$ Recebido para publicação em 29/01/2014; aprovado em 20/06/2014

Trabalho desenvolvido durante a disciplina de Física do Solo do Programa de Pós Graduação em Solos e Nutrição de Plantas ESALQ/USP

${ }^{2}$ Departamento de Ciências do Solo, Universidade Federal do Ceará, Av. Mister Hull, 2977, Presidente Kennedy, Fortaleza-CE, Brasil, 60.021-970, jblum@ufc.br

${ }^{3}$ Departamento de Ciência do Solo e Engenharia Agrícola, Universidade Estadual de Ponta Grossa, Ponta Grossa-PR, Brasil, neydegiarola@ gmail.com

${ }^{4}$ Departamento de Ciência do Solo/Universidade de São Paulo, Escola Superior de Agricultura Luiz de Queiroz, Piracicaba-SP, Brasil, apisilva@usp.br, samalaglicia@gmail.com

${ }^{5}$ Instituto de Ciências Agrárias e Tecnológicas, Universidade Federal de Mato Grosso, Rondonópolis-MT, Brasil, osvaldoguedes@ yahoo.com.br ${ }^{6}$ Companhia Nacional de Abastecimento, Cuiabá-MT, Brasil, diogone @ yahoo.com.br

${ }^{7}$ Instituto Sócio Ambiental e Recursos Hídricos/ISARH, Universidade Federal Rural da Amazônia, Belém-PA, Brasil, suzana.araujo@ufra.edu.br
} 


\section{INTRODUCTION}

The no-till system capacity to reduce losses of soil, water, and nutrients caused by water erosion is widely known, as well as to increase soil water holding capacity, organic matter, and nutrients (DERPSCH et al., 2010). Because of all these advantages, it is considered the most important system for conservation and maintenance of soil productive capacity in tropical regions (MARCHÃO et al., 2007; TORRES; PEREIRA; FABIAN, 2008). However, soil nondisturbance, combined with heavy machinery traffic, may change soil structure over time, leading to modifications in pore size and distribution patterns (TORMENA et al., 2002). As soil cultivation under no-till system is restricted to the sowing row, the presence of a compacted layer has been frequently observed, which is considered one of the major obstacles for productivity increase. Soil compaction is quite common in areas under long term no-till system (TORMENA et al., 2002), especially in soils of high clay contents (SECCO et al., 2004).

Mechanical chiseling has been adopted by farmers as an alternative to alleviate surface compaction in notill systems (JIN et al., 2007). Chiseling breaks the compacted layer, improving soil water holding capacity, water infiltration, and porosity, and reducing bulk density (PANACHUKI et al., 2011).

Despite the evidence that, under no-till, bulk density increases and soil porosity decreases, no detrimental effects have been observed on crop productivity in several studies (CARDOSO et al., 2006, SILVA et al., 2012, SPERA et al., 2004). Lack of negative responses may probably be related to the sowing operation. There were some difficulties, during the no-till system initial development, in achieving the appropriate seed and fertilizer positioning. These problems were related to the difficulty of straw cutting on soil surface and disc insertion into the compacted soil, and were overcome with development of disc systems for straw cutting associated with a furrow opener shank that penetrates the soil, placing fertilizers and seeds at the adequate depth (CEPIK; TREIN; LEVIEN, 2005). The use of furrow opener shanks, besides providing proper positioning and seed burial, locally mobilizes the soil, creating two distinct regions: sowing row and inter-row, showing differences regarding soil physical properties.

Improvements of soil physical quality at sowing rows were verified by Tormena et al. (2008) by using Sindex. Nevertheless, there are few studies in the literature regarding evaluations of soil physical conditions resulting from sowing operations under no-till systems. Thus, studies on differences of soil physical quality between row and inter-row positions are necessary, as well as on how it affects crop development.
Our hypothesis is that the furrow opener shank, used during soybean sowing (Glycine max L.) under notill system, would result in better soil physical conditions at sowing row position. The objective of this study was to evaluate the effect of soybean sowing with a furrow opener shank on soil physical properties in a Typic Hapludox under a 16-year no-till system.

\section{MATERIAL AND METHODS}

The study site is located in Ponta Grossa, Paraná State, Brazil (1,100 m above sea level) (Figure 1). According to Köppen classification, the climate regime is $\mathrm{Cfb}$ (Humid Subtropical Mesothermal), with mean annual rainfall of $1,545 \mathrm{~mm}$ and mean annual temperature of $18.7^{\circ} \mathrm{C}$ (IAPAR, 2000). The study site is located on a slope top at about $1,050 \mathrm{~m}$ above sea level, presenting 3 to $8 \%$ slope. The predominant soil type is Typic Hapludox, which, according to the Brazilian classification, is clayey Red Latosol (SANTOS et al., 2006).

The area has been cultivated for 16 consecutive years under no-till system, and submitted to crop rotation with maize (Zea mays L.) and soybean (Glycine max L.) in spring and summer, and wheat (Triticum aestivum L.), black oat (Avena strigosa Schreb), and vetch (Vicia sativa L.) in autumn and winter. Crop sowing in the spring/summer seasons was performed with a no-till planter equipped with a furrow opener shank. This operation causes soil disturbance only at the sowing row to place seeds at $0.04 \mathrm{~m}$ depth, and fertilizers at $0.1 \mathrm{~m}$ depth.

Soybean seeds were sown in November 2008, and soil sampling was carried out after soybean harvest in April 2009. An L-shaped transect was used to delimit 34 sampling points (Figure 1). Soil samples were collected at both, sowing row and inter-row positions, at each sampling point, resulting in 68 samples. Undisturbed samples $(0.05 \mathrm{~m}$ diameter and $0.05 \mathrm{~m}$ height) were collected using an electro-mechanical soil sampler developed by Figueiredo (2010), which introduced the ring into the soil at a fixed rate of $2 \mathrm{~mm} \mathrm{~s}^{-1}$, avoiding mechanical impact and disturbance. Samples were packed in plastic bags and sent to the laboratory, where were maintained at the temperature of $5^{\circ} \mathrm{C}$ until processing.

Samples were prepared and submitted to saturation by the gradual elevation of the water level. Saturated hydraulic conductivity (Ksat) was obtained according to the decreasing load method (REYNOLDS; ELRICK, 2002). A cylindrical ring without soil was fixed on the top of another cylindrical ring with soil, laterally sealing them. Cylinders were then placed in a container, which was gradually filled with water until overflow into the 
Figure 1 - Location of the study area and distribution of the sampling points $\left(25^{\circ} 06^{\prime} \mathrm{S}\right.$ and $\left.50^{\circ} 03^{\prime} \mathrm{W}\right)$

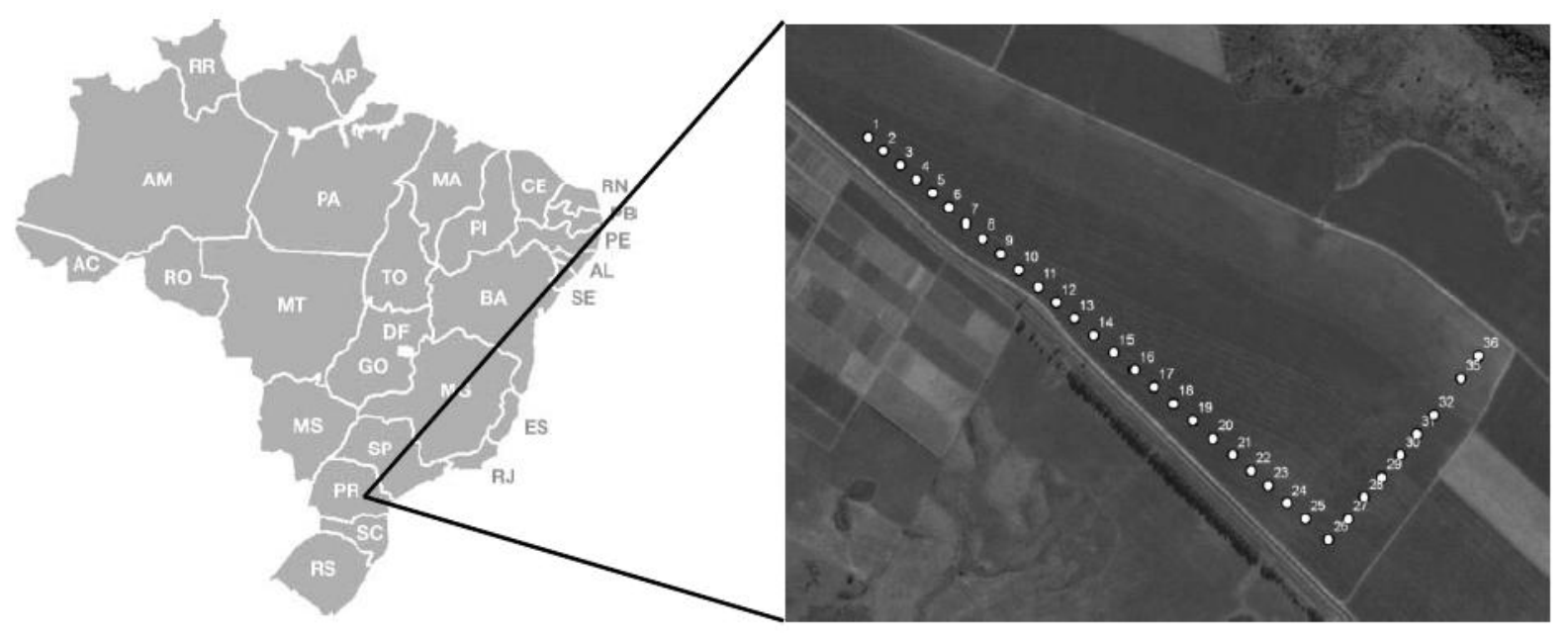

ring without soil. A hole at the bottom of the container was opened, allowing water drainage from the container and establishing the water flow through the soil sample. Water displacement through the soil sample, with height $L$ at time $t$, corresponded to the water displacement between two heights $\left(h_{0}\right.$ and $\left.h_{l}\right)$. Heights $\mathrm{h}_{0}$ and $\mathrm{h}_{1}$ were measured with a wire structure placed on soil surface inside the empty ring. The Ksat was calculated by Equation 1:

$$
K s a t=\left(\frac{L}{t}\right) x \ln \left(\frac{h_{0}}{h_{1}}\right)
$$

where $L, h_{0}$, and $h_{1}$ are heights, in meters (m); $t$ is the time, in seconds (s); and Ksat is the hydraulic conductivity of the saturated soil $\left(\mathrm{mm} \mathrm{h}^{-1}\right)$.

After measurement of the saturated hydraulic conductivity, soil samples were placed on a suction table and submitted to the potential of $-10 \mathrm{kPa}$ (field capacity). Once equilibrium was reached, samples were weighed to calculate the water content at field capacity; air permeability $(K a)$ was determined for each soil sample using a constant air load permeameter developed by Figueiredo (2010). The operating principle of this device consists of submitting an undisturbed soil sample, wrapped in a volumetric ring with free flow of gases at their ends, to successive increments of air flow rates to generate pressure gradients. From stabilization of the air flow, and determination of the potential difference required to the air flow pass through the sample, $K a$ at constant load (BALL; SCHJONNING, 2003) was calculated by Equation 2:

$$
k a=\frac{q_{v}}{\Delta P_{a}} 0.7975
$$

where $q_{v}$ is the airflow, in $\mathrm{cm}^{3} \mathrm{~min}^{-1}, K a$ is the air permeability, in $\mu \mathrm{m}^{2}$, and $\Delta P_{a}$ is the potential difference required to the air flow pass through the sample.

Particle size, bulk density, and particle density were determined according to Blake and Hartge (1986), by the densimeter, volumetric ring, and helium gas pycnometer (model AccuPyc 1330) methods, respectively. Total porosity (TP), in $\mathrm{m}^{3} \mathrm{~m}^{-3}$, was calculated from the bulk density (Bd) and particle density (Pd) by Equation 3:

$$
T P=1-\left(\frac{B d}{P d}\right)
$$

Soil water content at field capacity was determined after moisture stabilization at the potential of $-10 \mathrm{kPa}$. Macroporosity (MP) was calculated as the difference between TP and moisture at field capacity. Organic carbon was determined by wet oxidation (EMBRAPA, 1997).

Data were submitted to paired t test to compare the soil physical properties between row and inter-row positions along the transect, considering the sampling point. Correlation analyses were performed among soil physical properties and multiple regression models fitted to quantify the influence of soil texture, sampling position, and organic matter on the other soil physical properties. All analyses and adjustments were performed using the statistical software $\mathrm{R}$ (R DEVELOPMENT CORE TEAM, 2009).

\section{RESULTS AND DISCUSSION}

A textural variation, ranging from 150 to $460 \mathrm{~g} \mathrm{~kg}^{-1}$ of clay, was observed along the transect (Table 1), proving to be appropriate for this study purpose, which was to 
assess the effects of sowing operation on soil physical properties in a wide textural range. A large range of carbon concentration was also observed along the transect (Table 1), showing positive correlation with clay content $(r=0.80$, $\mathrm{p}<0.001$ ). This corroborates the results obtained by Zinn, Lal, and Resck (2005), who also reported a correlation between these two variables. Such relationship may be attributed to the physical protection effect promoted by the organic matter within stable microaggregates in clayey soils (SCHIMIDT et al., 2011). Watts et al. (2006) also observed that the amount of soil organic carbon raised with increasing clay content, confirming that clay provides physical protection to soil carbon, hindering its microbial decomposition.

Bulk density varied from 1.05 to $1.5 \mathrm{Mg} \mathrm{m}^{-3}$, showing an inversely proportional distribution related to clay and organic carbon contents (Figure 2). In the stepwise multiple regression adjustment, bulk density $(\mathrm{Bd})$ varied according to clay content and sampling position (pos) (Equation 4). Although there is a general agreement that bulk density varies with organic carbon (GARCÍA-ORENES et al., 2005), and a simple negative correlation between these variables was even verified in this study $(\mathrm{r}=-0.47, \mathrm{p}<0.001)$, it was not possible to establish a multiple correlation between them because of the organic carbon dependence on clay content.
$\mathrm{Bd}\left(\mathrm{Mg} \mathrm{m}^{-3}\right)=1.42 * * *-0.0083$ clay $^{* * *}+0.129$ pos $^{* * *}$;

$\mathrm{R}^{2}=0.52 ; \mathrm{p}<0.001$

$* * * \mathrm{p} \leq 0.001$ (For coefficients of each variable).

The insertion of the qualitative variable position in the multiple regression was possible via the attribution of the values zero to row $(R=0)$, and one to inter-row $(\mathrm{IR}=1)$ positions. The position coefficient indicates absolute differences of the analyzed variable for interrow position in relation to the row (Equation 4). Bulk density at inter-row was $0.129 \mathrm{Mg} \mathrm{m}^{-3}$ higher than at row position. The lower bulk density at row position is due to the partial soil mobilization resulting from sowing operation and, also, to the action of different root systems derived from crop rotation. Tormena et al. (2008) found similar results, however, in a much higher clay content than in this study.

Total porosity varied from 0.42 to $0.61 \mathrm{~m}^{3} \mathrm{~m}^{-3}$ (Table 1). The lower porosity values were found close to point 9 , and higher values, close to point 15 , what coincides with the minimum and maximum clay contents, respectively (Figure 3). The better multiple regression adjustment considered $\mathrm{TP}$ as a function of clay and sampling position (Equation 5).

Table 1- Statistical parameters of the analyzed soil physical attributes

\begin{tabular}{|c|c|c|c|c|c|c|}
\hline Attributes & Position & Minimum & Mean & Maximum & SD & $\mathrm{CV}$ \\
\hline \multirow{2}{*}{ Clay $\left(\mathrm{g} \mathrm{kg}^{-1}\right)$} & IR & 150.2 & 291.2 & 464.4 & 84.4 & 28.98 \\
\hline & $\mathrm{R}$ & 162.5 & 289.1 & 463.9 & 79.4 & 27.46 \\
\hline \multirow{2}{*}{ Carbon $\left(\mathrm{g} \mathrm{kg}^{-1}\right)$} & IR & 10.91 & 22.14 & 33.55 & 6.17 & 27.87 \\
\hline & $\mathrm{R}$ & 9.66 & 22.04 & 34.85 & 6.58 & 29.85 \\
\hline \multirow{2}{*}{$\mathrm{Bd}\left(\mathrm{Mg} \mathrm{m}^{-3}\right)$} & IR & 1.05 & 1.3 & 1.5 & 0.1 & 7.69 \\
\hline & $\mathrm{R}$ & 0.99 & 1.18 & 1.47 & 0.12 & 10.17 \\
\hline \multirow{2}{*}{ Ksat $\left(\mathrm{mm} \mathrm{h}^{-1}\right)$} & IR & 3.63 & 242.4 & 1077 & 264.82 & 109.25 \\
\hline & $\mathrm{R}$ & 20.35 & 649.1 & 1523 & 442.78 & 68.21 \\
\hline \multirow{2}{*}{$\mathrm{Ka}\left(\mu \mathrm{m}^{2}\right)$} & IR & 0.69 & 2.34 & 7.48 & 1.73 & 73.93 \\
\hline & $\mathrm{R}$ & 0.45 & 5.57 & 9.97 & 2.84 & 50.99 \\
\hline \multirow{2}{*}{$\operatorname{Mp}\left(\mathrm{m}^{3} \mathrm{~m}^{-3}\right)$} & IR & 0.06 & 0.17 & 0.29 & 0.062 & 36.47 \\
\hline & $\mathrm{R}$ & 0.05 & 0.24 & 0.31 & 0.062 & 25.83 \\
\hline \multirow{2}{*}{$\theta_{\mathrm{FC}}\left(\mathrm{m}^{3} \mathrm{~m}^{-3}\right)$} & IR & 0.18 & 0.32 & 0.43 & 0.059 & 18.44 \\
\hline & $\mathrm{R}$ & 0.19 & 0.29 & 0.43 & 0.063 & 21.72 \\
\hline \multirow{2}{*}{$\theta \mathrm{WP}\left(\mathrm{m}^{3} \mathrm{~m}^{-3}\right)$} & IR & 0.04 & 0.09 & 0.15 & 0.031 & 34.44 \\
\hline & $\mathrm{R}$ & 0.03 & 0.08 & 0.15 & 0.029 & 36.25 \\
\hline \multirow{2}{*}{$\mathrm{TP}\left(\mathrm{m}^{3} \mathrm{~m}^{-3}\right)$} & IR & 0.42 & 0.49 & 0.59 & 0.038 & 7.79 \\
\hline & $\mathrm{R}$ & 0.43 & 0.54 & 0.61 & 0.045 & 8.37 \\
\hline
\end{tabular}

$\mathrm{SD}=$ standard deviation; $\mathrm{CV}=$ coefficient of variation; $\mathrm{R}=$ row; $\mathrm{IR}=$ inter-row; $\mathrm{Bd}=$ bulk density; Ksat = hydraulic conductivity; Ka = air permeability; $\mathrm{Mp}=$ macroporosity; $\theta_{\mathrm{FC}}=$ field capacity $(-10 \mathrm{kPa}) ; \theta \mathrm{wP}=$ wilting point; $\mathrm{TP}=$ total porosity 
$\mathrm{TP}\left(\mathrm{m}^{3} \mathrm{~m}^{3}\right)=0.458 * * *+0.003$ clay $^{*} * *-0.05$ pos $^{* * *}$;

$\mathrm{R}^{2}=0.47 ; \mathrm{P}<0.001$

$* * * \mathrm{p} \leq 0.001$ (For coefficients of each variable).

The positive correlation between clay and soil porosity is due to the high microporosity found in clayey soils. Soil samples collected at the sowing row showed $0.05 \mathrm{~m}^{3} \mathrm{~m}^{-3}$ more pores than at inter-row, what implies a difference of $5 \%$ between positions. This indicates that porosity results were similar to bulk density, as both demonstrated better soil physical conditions at the sowing line (row position). This result is important for crop germination and emergence since, in no-till systems, sowing is the main responsible operation for the formation of an appropriate seedbed (GUEDES FILHO et al., 2013). Tebrügge and Düring (1999) demonstrated that, after plowing, the conventional tillage had higher TP than no-till system; however, after seven months, pore quantity was equivalent in both systems. In this study, after a similar

Figure 2 - Clay, organic carbon, and bulk density at row (R) and inter-row (IR) positions along the studied area in a Typic Hapludox under no-till system
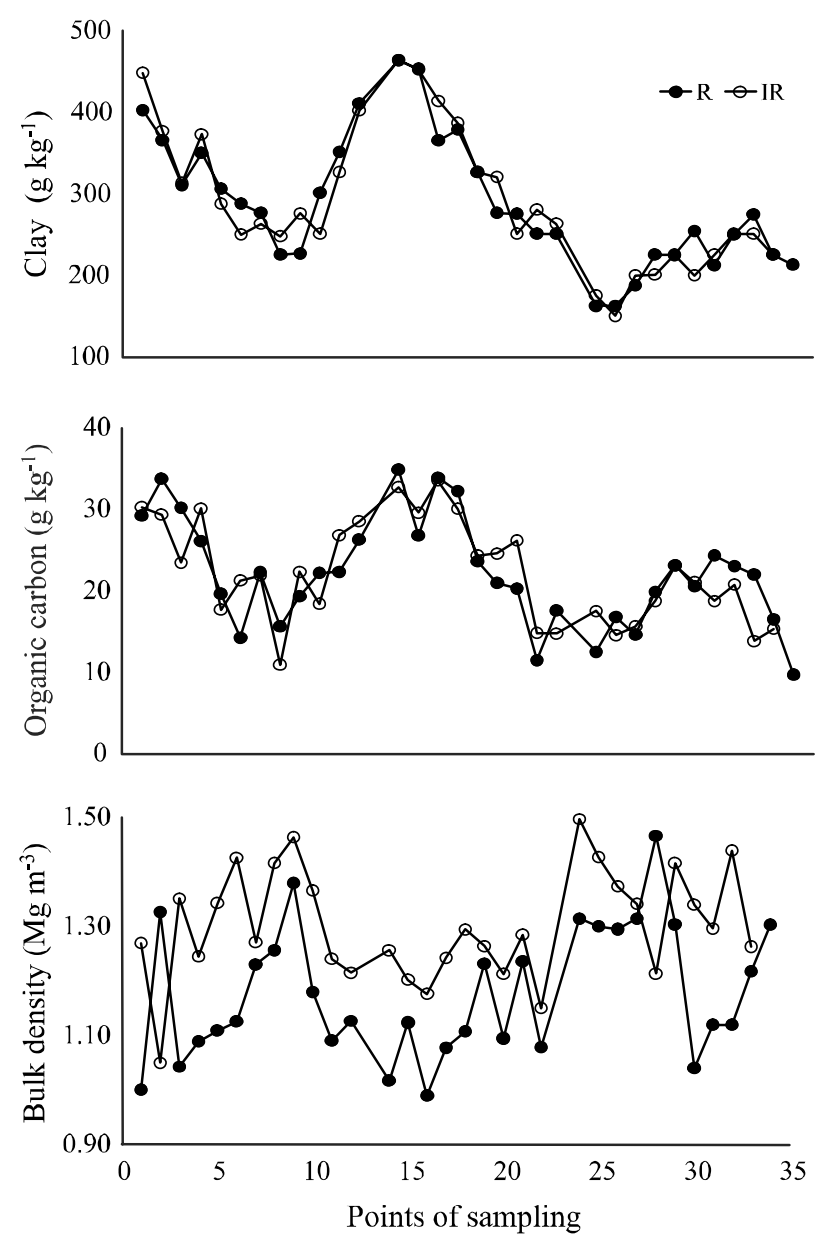

period, the permanence of pores at the sowing line indicates that mobilization caused by the seeder, as well as by the root system action, resulted in more stable pores than those produced in conventional tillage.

Figure 3 - Total porosity (TP), macroporosity (MP), and field capacity $\left(\theta_{\mathrm{FC}}\right)$ of the soil at row (R) and inter-row (IR) positions along the studied area in a Typic Hapludox under no-till system
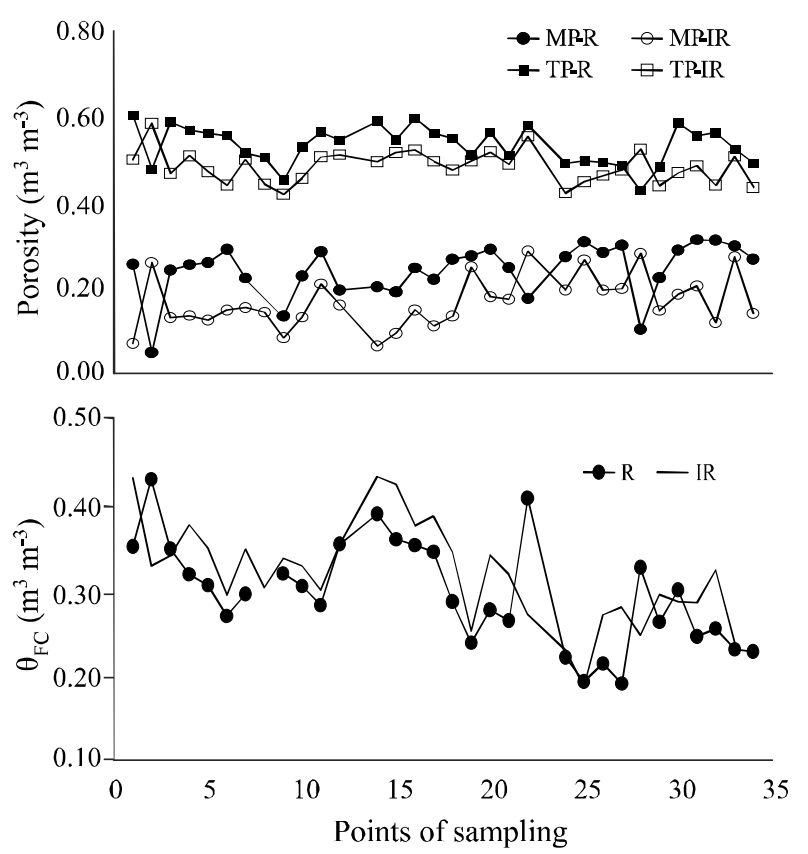

The MP variation amplitude ranged from 0.05 to $0.31 \mathrm{~m}^{3} \mathrm{~m}^{-3}$, showing a higher variation than TP (Table 1). This may be explained by the effect of the sampling position, which was confirmed by the higher position coefficient in equation 6 , in comparison with equation 5 . Therefore, this confirms the higher pore stability resulting from the drilling operation. Macroporosity directly depends on soil sand content (NAVEED et al., 2013), hence showing a negative relationship with soil clay content (Equation 6).

$$
\begin{aligned}
& \mathrm{MP}=0.33 * * *-0.003 \text { clay } * * *-0.074 \text { pos }_{* * *} ; \\
& \mathrm{R}^{2}=0.39 ; \mathrm{P}<0.001 \\
& * * * \mathrm{p} \leq 0.001 \text { (For coefficients of each variable). }
\end{aligned}
$$

Water content at field capacity $\left(\theta_{\mathrm{FC}}\right)$ varied from 0.18 to $0.43 \mathrm{~m}^{3} \mathrm{~m}^{-3}$, with higher dependence on soil texture in relation to TP and MP, what is demonstrated by the higher clay coefficient in equation 7 , in comparison with equation 5 and 6 . The lower coefficient of the variable position, in comparison with TP and MP, showed that field capacity was the most stable measured soil property, therefore, with smaller alterations according to soil management. 
$\Theta_{\mathrm{FC}}=0.126 * * *+0.0057$ clay $* * *+0.0228$ pos $*$;

$\mathrm{R}^{2}=0.62 ; \mathrm{P}<0.001$

$*$ and $* * *, \mathrm{p} \leq 0.05$ and 0.001 , respectively (For coefficients of each variable)

Soil dynamic properties Ksat and Ka showed similar tendency along the transect (Figure 4), with higher values at the sowing row position. However, Ka presented lower coefficient of variation (Table 1). Both soil properties, Ksat and $\mathrm{Ka}$, were positively correlated with MP $(r=0.75$ and 0.74 , respectively, $\mathrm{p}<0.001)$. Positive correlations were expected since these soil properties derive from the same soil pore space (MESQUITA; MORAES, 2004). Also, the dependence of both variables on soil porosity may explain the significant correlation between both $(r=0.77, \mathrm{p}<0.001)$. The relationship among Ksat and Ka, and MP and sampling position may also be due to continuum channels formed after the plant root decay (TAVARES FILHO et al., 2001). Multiple correlations fitted showed a log variation of Ksat and $\mathrm{Ka}$ due to the dependence of these soil properties on bulk density and clay content (Equation 8 and 9).

$\log ($ Ksat $)=19.50 * * *-8.73 \mathrm{Bd}^{* * *} *-0.107 \mathrm{clay} * * * ;$

$\mathrm{R}^{2}=0.53 * * *$

$\log (\mathrm{Ka})=9.28 * * *-5.04 \mathrm{Bd}^{* * *}-0.067 \mathrm{clay}^{* * * *} ;$

$\mathrm{R}^{2}=0.52 * * *$

$* * * \mathrm{p} \leq 0.001$ (For coefficients of each variable).

Figure 4 - Saturated hydraulic conductivity (Ksat) and air permeability (Ka) variations at row (R) and inter-row (IR) positions along a Typic Hapludox transect under no-till system
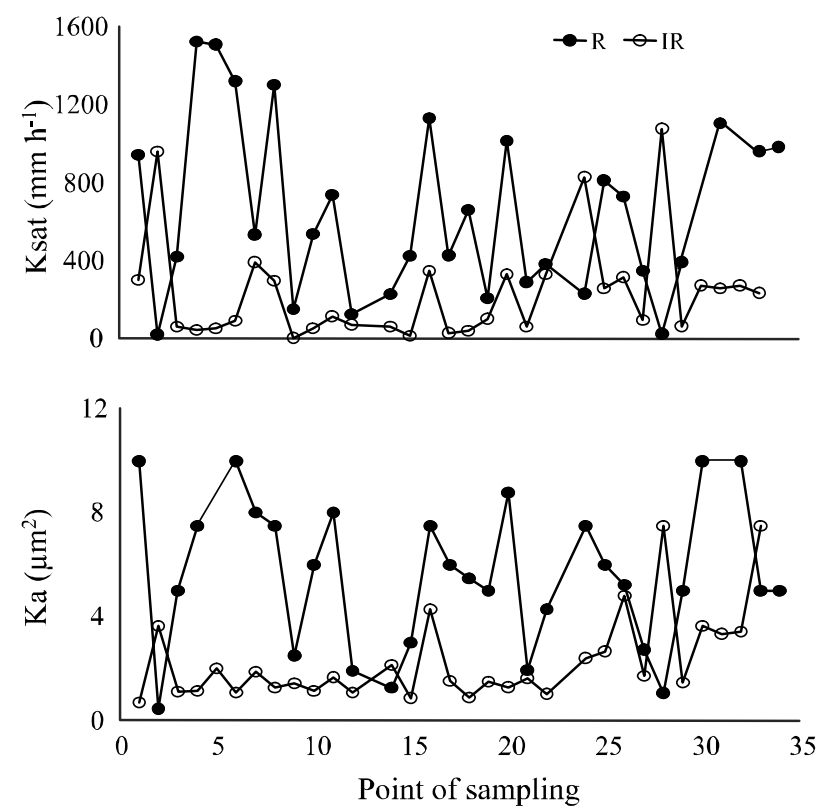

The paired $\mathrm{t}$ test showed no textural or soil organic carbon differences between row and interrow positions (Table 2). The lack of sampling position effect on soil texture was expected, since granulometric fractions are independent of short term soil management. Organic carbon is usually affected by soil management in long term experiments (LUCIANO et al., 2010). However, the short period from the seed drill operation to soil sampling in this study also may explain the lack of effect. These results enabled the hypothesis test that the seed drill operation would create better soil conditions. Due to the fact that texture and organic carbon can interfere in the evaluated soil properties, any difference in these parameters between sowing row and inter-row would bias the effect of the seed drill operation on other soil properties.

Table 2 - Paired t test values, error probability, and mean differences of soil attributes between row and inter-row sampling positions in a Typic Hapludox under no-till system

\begin{tabular}{lrrr}
\hline Soil attributes & Paired t value & Probability & \multicolumn{1}{c}{$\begin{array}{c}\text { Mean } \\
\text { differences }\end{array}$} \\
\hline Bd $\left(\mathrm{Mg} \mathrm{m}^{-3}\right)$ & 5.42 & 0.000006 & 0.12 \\
Ksat $\left(\mathrm{mm} \mathrm{h}^{-1}\right)$ & -3.89 & 0.00053 & -408.66 \\
$\mathrm{Ka}\left(\mathrm{\mu m}^{2}\right)$ & -4.97 & 0.000027 & -3.26 \\
Carbon $\left(\mathrm{g} \mathrm{kg}^{-1}\right)$ & 0.14 & 0.88 & 0.10 \\
Clay $\left(\mathrm{g} \mathrm{kg}^{-1}\right)$ & 0.44 & 0.66 & 0.21 \\
Silt $\left(\mathrm{g} \mathrm{kg}^{-1}\right)$ & 0.33 & 0.74 & 0.14 \\
Sand $\left(\mathrm{g} \mathrm{kg}^{-1}\right)$ & -0.26 & 0.79 & -0.13 \\
$\mathrm{TP}\left(\mathrm{m}^{3} \mathrm{~m}^{-3}\right)$ & -5.44 & 0.000006 & -0.05 \\
$\mathrm{MP}\left(\mathrm{m}^{3} \mathrm{~m}^{-3}\right)$ & -4.51 & 0.00009 & -0.07 \\
$\theta \mathrm{FC}\left(\mathrm{m}^{3} \mathrm{~m}^{-3}\right)$ & 2.50 & 0.018 & 0.023 \\
\hline
\end{tabular}

$\mathrm{Bd}=$ bulk density; Ksat = saturated hydraulic conductivity; $\mathrm{Ka}=$ air permeability; $\theta_{\mathrm{FC}}=$ field capacity $(-10 \mathrm{kPa}) ; \mathrm{TP}=$ total porosity

There were differences for all studied soil properties (Bd, Ksat, Ka, TP, MP, and $\theta_{\mathrm{FC}}$ ) between row and inter-row positions (Table 2). Better soil physical conditions were observed at row position in the entire textural range, which varied from 150 to $464 \mathrm{~g} \mathrm{~kg}^{-1}$ of clay. In addition, such clay range may be extended to $800 \mathrm{~g} \mathrm{~kg}^{-1}$ based on the results presented by Tormena et al. (2008), who also observed improvements in soil conditions at row position.

Bulk density was, on average, $0.12 \mathrm{Mg} \mathrm{m}^{-3}$ lower at row position. The lower bulk density was directly related to the higher $\mathrm{TP}$ at row position (Equation 5). 
Higher $\mathrm{t}$ values for $\mathrm{TP}$ and $\mathrm{Bd}$ revealed the higher sensibility of these two parameters to soil mobilization at the sowing row. Additionally, Ksat, Ka, and MP also showed differences between row and inter-row positions, with significance probability lower than 0.001. This result evidences that these soil properties are also sensitive to management; it may be used for the impact quantification of soil use, corroborating the results observed by Cavalieri et al. (2009).

Soil quality improvement at row position shows that there are compaction problems in no-till systems. This soil surface compaction is due to the lack of cultivation and, also, to traffic of tractors and implements (LUCIANO et al., 2010). However, drilling operations with a furrow opener shank can minimize this compaction by creating a more favorable physical environment to seed germination and plant emergence, ensuring better plant population and productivity.

\section{CONCLUSION}

Seed drill operations in no-till systems, using a furrow opener shank, improved soil physical quality at the sowing row. This better physical quality is represented, in a wide textural range, by lower bulk density, and higher total porosity, macroporosity, saturated hydraulic conductivity, and air porosity.

\section{ACKNOWLEDGEMENTS}

The authors thank the Graduate Program in Soil and Plant Nutrition and the Soil Science Depatment from ESALQ/USP for providing funding, structure and resource materials for developing the research work. The authors also thank the School Farm "Capão da Onça", State University of Ponta Grossa (UEPG), for providing the experimental field for sample collection.

\section{REFERENCES}

BALL, B. C.; SCHJONNING, P. Air permeability. In: DANE, J. H.; TOPP, G. C. Methods of soil analysis. $3^{\text {rd }}$ ed. Madison: Soil Science Society of America, 2003. Pt. 4: Physical methods, p. 1141-1158.

BLAKE, G. R.; HARTGE, K. H. Bulk density. In: KLUTE, A. (Ed.) Methods of soil analisys: physical and mineralogical methods. 2. Ed. Madson: American Society of Agronomy, 1986. cap. 13 , p. 363-375.

CARDOSO, E. D. et al. Sistema radicular da soja em função da compactação do solo no sistema de plantio direto. Pesquisa Agropecuária Brasileira, v. 41, n. 3, p.493-501, 2006.
CAVALIERI, K. M. V. et al. Long-term effects of no-tillage on dynamic soil physical properties in a Rhodic Ferrasol in Paraná, Brazil. Soil and Tillage Research, v.103, p. 158164, 2009.

CEPIK, C. T. C.; TREIN, T. R.; LEVIEN, R. Força de tração e volume de solo mobilizado por haste sulcadora em semeadura direta sobre campo nativo, em função do teor de água no solo, profundidade e velocidade de operação. Engenharia Agrícola, v. 25, p. 447-457, 2005.

DERPSCH, R. et al. Current status of adoption of notill farming in the world and some of its main benefits. International Journal of Agricultural and Biological Engineering, v. 3, p. 1-25, 2010.

EMPRESA BRASILEIRA DE PESQUISA AGROPECUÁRIA. Centro Nacional de Pesquisa dos Solos. Manual de métodos de análise de solo. 2 ed. Rio de Janeiro, EMBRAPA - CNPS, 1997. $212 \mathrm{p}$.

FIGUEIREDO, G. C. Avanços metodológicos e instrumentais em física do solo. Piracicaba, Escola Superior de Agricultura "Luiz de Queiroz", 2010. 163p. (Tese de Doutorado).

GARCÍA-ORENES, F. et al. Factors controlling the aggregate stability and bulk density in two different degraded soils amended with biosolids. Soil and Tillage Research, v.82, p. 65-76, 2005.

GUEDES FILHO, O. et al. Structural properties of the soil seedbed submitted to mechanical and biological chiseling under no-tillage. Geoderma, v. 204-205, p. 94-101, 2013.

INSTITUTO AGRONÔMICO DO PARANÁ. Cartas climáticas do Paraná: edição ano 2000, versão 1.0. Londrina, 2000. 1 CD ROM.

JIN, H.; et al. The adoption of annual subsoiling as conservation tillage in dryland maize and wheat cultivation in northern China. Soil and Tillage Research, v. 94, n. 2, p. 493-502, 2007.

LUCIANO, R. et al. Propriedades físicas e carbono orgânico do solo sob plantio direto comparados à mata natural, num Cambissolo Háplico. Revista de Ciências Agroveterinárias. v. 9, n. 1, p. 09-19, 2010.

MARCHÃO, R. L. et al. Qualidade física de um Latossolo Vermelho sob sistemas de integração lavoura-pecuária no Cerrado. Pesquisa Agropecuária Brasileira, v. 42, p. 873882, 2007.

MESQUITA, M. G. B. F.; MORAES, S. O. A dependência entre a condutividade hidráulica saturada e atributos físicos do solo. Ciência Rural, v. 34, p. 963-969, 2004.

NAVEED, M. M. et al. Revealing Soil Structure and Functional Macroporosity along a Clay Gradient Using Xray Computed Tomography. Soil Science Society of America Journal, v. 77, p. 403-411, 2013.

PANACHUKI, E. et al. Perdas de solo e de água e infiltração de água em latossolo vermelho sob sistemas de manejo. Revista Brasileira de Ciência do solo, v.35, p.1777-1785, 2011. 
R DEVELOPMENT CORE TEAM (2009): A language and environment for statistical computing. $R$ Foundation for Statistical Computing, Vienna, Austria. ISBN 3-900051-07-0, URL http://www.R-project.org.

REYNOLDS, W. D., ELRICK, D. E. Pressure infiltrometer. In: DANE, J. H. E TOPP, G. C. Methods of Soil Analysis, Part 4: Physical Methods, Number 5 in the Soil Science Society of America Book Series, Madison, WI, 2002. p. 826-836.

SANTOS, H.G. et al. (Ed). Sistema brasileiro de classificação de solos, 2 ed. Rio de Janeiro: Embrapa Solos, 2006, 306 p.

SCHMIDT, M. W. I. et al. Persistence of soil organic matter as an ecosystem property. Nature, v. 477, p. 49-56, 2011.

SECCO, D. et al. Produtividade de soja e propriedades físicas de um Latossolo submetido a sistemas de manejo e compactação. Revista Brasileira de Ciência do Solo, v. 28, n. 5, p. 797-804, 2004.

SILVA, M. A. A. et al. Propriedades físico-hídricas, desenvolvimento radicular e produtividade da soja em dois tipos de manejos de solo. Irriga, v. 17, n. 3, p. 387-396, 2012.

SPERA, S. T. et al. Efeitos de sistemas de produção de grãos envolvendo pastagens sob plantio direto nos atributos físicos de solo e na produtividade. Revista Brasileira de Ciência do Solo, v. 28, n. 3, p. 533-542, 2004.

TAVARES FILHO, J. et al. Resistência do solo à penetração e desenvolvimento do sistema radicular do milho (Zea mays) sob diferentes sistemas de manejo em um Latossolo Roxo. Revista Brasileira de Ciência do Solo, v. 25, p. 725-730, 2001.

TEBRUGGE, F., DURING, R. A. Reduced tillage intensity. A review of results of a long-term study in Germany. Soil Tillage Research, v. 53, p. 15-28. 1999.

TORMENA, C. A. et al. Quantification of the soil physical quality of a tropical Rhodic Hapludox using the s index. Scientia Agricola, v. 65, p. 56-60, 2008.

TORMENA, C. A. et al. Densidade, porosidade e resistência à penetração em Latossolo cultivado sob diferentes sistemas de preparo do solo. Scientia Agricola, v. 59, p. 795-801, 2002.

TORRES, J. L. R.; PEREIRA, M. G.; FABIAN, A. J. Produção de fitomassa por plantas de cobertura e mineralização de seus resíduos em plantio direto. Pesquisa Agropecuária Brasileira, v.43, p.421-428, 2008.

WATTS, C. W. et al. The role of clay, organic carbon and long-term management on mouldboard plough draught measured on the Broadbalk wheat experiment Rothamsted. Soil Use and Management, v. 22, p. 334-341, 2006.

ZINN, Y. L.; LAL, T. R.; RESCK, D. V. S. Texture and organic carbon relations described by a profile pedotransfer function for Brazilian Cerrado soils. Geoderma, v. 127, p. 168-173, 2005. 